Journal of Clinical Investigation

Journal of Clinical In
Vol. 41, No. 7, 1962

\title{
EFFECTS OF SULFHYDRYL INHIBITION ON RED BLOOD CELLS. II. STUDIES IN VIVO*
}

\author{
BY HARRY S. JACOB AND JAMES H. JANDL \\ (From the Thorndike Memorial Laboratory and Second and Fourth (Harvard) Medical \\ Services, Boston City Hospital, and the Department of Medicine, \\ Harvard Medical School, Boston, Mass.)
}

(Submitted for publication January 17, 1962; accepted February 26, 1962)

A failure of metabolic processes in red cells is believed to initiate changes leading to their sequestration and destruction in the reticuloendothelial system, principally in the liver and spleen $(1,2)$. Since red cells derive virtually all of their energy from glucose, it appears that the decline in activity of certain glycolytic enzymes during normal red cell aging may determine the life span of the cell (3-5). The rate of "senescence" is somewhat increased in red cells of subjects whose oxidative shunt (pentose phosphate pathway) is impaired by a deficiency of the enzyme, glucose-6-phosphate dehydrogenase (G6PD) $(6,7)$, and is greatly increased in red cells defective in the main glycolytic pathway, as by a deficiency of pyruvate kinase (8). Applying stress to such defective red cells, e.g., by administering a potentially oxidant compound to G6PD-deficient subjects, markedly accelerates the rate of cell damage and destruction $(9,10)$.

The way in which defective glycolysis causes the red cell to be recognized, trapped, and destroyed by reticuloendothelial cells is not known, although it is reasonable to assume that ultimately the red cell membrane must be altered, since it is the surface of the cell that comes in contact with the erythroclastic cells.

Subsequent to the work of others (11-14) indicating that sulfhydryl compounds are involved in certain hemolytic mechanisms, evidence was presented in a preceding paper (15) that the shape and viability of red cells in vitro depend upon the maintenance of membrane sulfhydryl groups. When these groups are blocked by specific inhibitors, the red cells undergo the following sequence of events : 1 ) cation gradients across the cell membrane are disrupted, with a cellular loss of $\mathrm{K}^{+}$and a gain of $\mathrm{Na}^{+} ; 2$ ) the resulting unopposed

* This work was supported by Grant RG3507 (C8) from the National Institutes of Health, Bethesda, Md. oncotic pressure of hemoglobin and other intracellular macromolecules causes an influx of water leading to cellular swelling and spherocytosis; and 3) ultimately the cell membrane becomes distended, permitting the leakage of hemoglobin (i.e. hemolysis). It was suggested that this sequence of events, observed after the addition of specific sulfhydryl inhibitors, may be likened to the sequence of cellular injury in various hemolytic processes. Accordingly, studies were made, and are presented here, of the behavior of sulfhydrylinhibited red cells in man and in rats, the findings in vivo being correlated with the physical and biochemical alterations produced. A preliminary report has been published (16).

\section{METHODS}

As in the previous studies (15) the sulfhydryl inhibitors employed were $p$-mercuribenzoate (PMB), 1 which does not penetrate the intact red cell membrane $(15,17)$, and $\mathrm{N}$-ethylmaleimide (NEM), ${ }^{2}$ which rapidly permeates the normal red cell $(15,18)$. The inhibitors were dissolved in physiologic saline and were rendered sterile by Seitz filtration shortly before use. Although quite different chemically, both compounds react rather specifically with sulfhydryl groups, and both cause very similar damage to the red cell membrane (15). Accordingly, their effects will be attributed throughout this paper to specific reactions with sulfhydryl groups and will be referred to as involving sulfhydryl "inhibition" or "blockade." It should be recognized that this inference is based upon circumstantial evidence, as is the case with other inhibitors.

Techniques applicable to studies in man. Unless otherwise stated, $25 \mathrm{ml}$ of blood from hematologically normal subjects was collected with sterile precautions in acidcitrate-dextrose (ACD) solution, and the cells labeled with $\mathrm{Cr}^{51}$ by incubation for 30 minutes at room tempera-

1 PMB was obtained as the $\mathrm{Na}$ salt of $p$-hydroxymercuribenzoate from Sigma Chemical Co., St. Louis, Mo. This chemical has been shown by the manufacturer to be free of $\mathrm{Hg}^{2+}$ by the $\mathrm{HgS}$ precipitation method.

2 Obtained from Schwarz Bioresearch, Inc., Mt. Vernon, N. Y. 

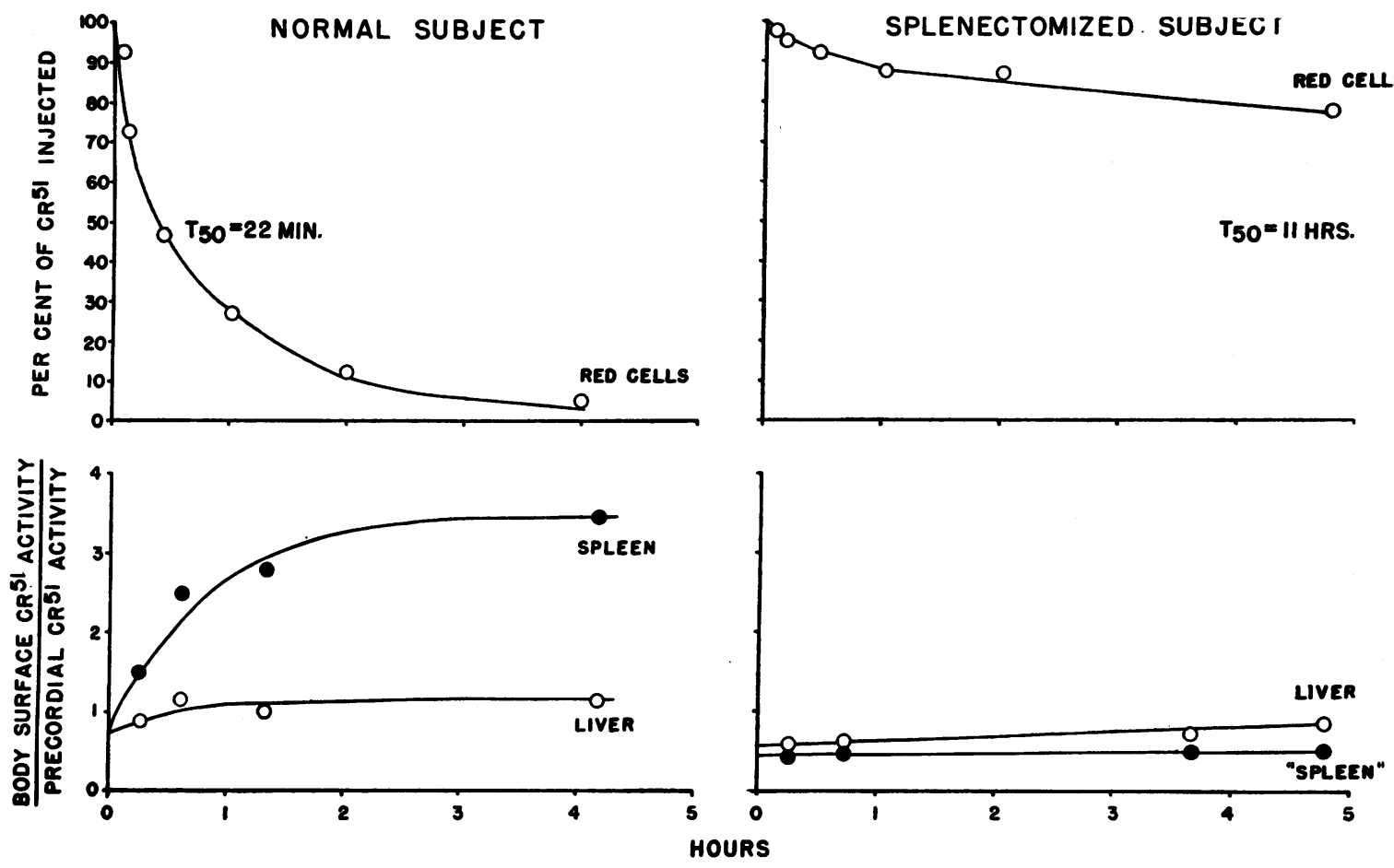

Fig. 1. Destruction of RED cells tReAted with NEM. In the normal subject (left) red cells labeled with $\mathrm{Cr}^{51}$, and treated with a concentration of NEM sufficient to inhibit cellular GSH, are rapidly removed in an exponential fashion from the circulation (left, top). These cells are selectively trapped in the spleen (left, bottom). In the splenectomized subject (right) survival of similarly treated red cells is prolonged 30 -fold without evidence of specific organ sequestration.

ture with 100 to $200 \mu \mathrm{c}$ of $\mathrm{Na}_{2} \mathrm{Cr}^{51} \mathrm{O}_{4} \cdot 3$ The labeled cell suspension, washed once and brought back to a 50 per cent cell suspension in sterile physiologic saline, was further incubated with an equal volume of inhibitor. Although incubation of cells with inhibitor for 15 minutes produced near maximal effects on red cell survival, a 1-hour incubation period was used in most experiments. Thereafter the cells were washed once and resuspended at a 50 per cent concentration in sterile saline. The labeled red cells were injected rapidly into the antecubital vein of the donor. At various intervals blood was drawn into 3 per cent sodium citrate $(9 \mathrm{ml}$ blood- $1 \mathrm{ml}$ citrate) for measurement of whole blood and plasma radioactivity in a well-type scintillation counter. The plasma was also quantitatively analyzed for bilirubin $(19,20)$ and for hemoglobin by the benzidine method (21). At less frequent intervals blood was also collected in oxalate for determinations of osmotic fragility. The fragility of the circulating $\mathrm{Cr}^{51}$-labeled cells was followed at various intervals after injection by comparing the radioactivity and hemoglobin concentration of the spun supernatants from blood added to graded hypotonic salt solutions [the previously described differential osmotic fragility technique $(22,23)]$.

Sites of cell sequestration were determined by body-

3 Abbott Laboratories, North Chicago, Ill. surface monitoring over spleen, liver, and precordium as previously described (24).

In preliminary work the possible effects of NEM and PMB on the uptake and elution of $\mathrm{Cr}^{51}$ by red cells were studied in vitro. Neither agent appreciably affected the cellular uptake of $\mathrm{Cr}^{51}$ as $\mathrm{Na}_{2} \mathrm{Cr}^{51} \mathrm{O}_{4}$, whether the inhibitor was added to the cell suspension before or after the $\mathrm{Cr}^{51}$. The elution of $\mathrm{Cr}^{51}$ from red cells exposed to these inhibitors was observed over a 48-hour period of sterile incubation in buffered saline and in serum. Although elution from inhibited cells somewhat exceeded that of the control cells in this period, this was largely accounted for by their increased autohemolysis. When the ratio of intracellular:extracellular $\mathrm{Cr}^{51}$ was corrected for autohemolysis, the rates of elution of $\mathrm{Cr}^{51}$ from control cells and from sulfhydryl-inhibited cells were comparable.

Red cell dimensions and concentrations were measured by standard techniques (21). The consumption of glucose by red cells was measured by the Somogyi-Nelson technique (25) ; their production of lactate was measured by the method of Barker and Summerson (26). Red cell glutathione (GSH) levels were determined by the nitroprusside method of Grunert and Phillips (27) as modified by Beutler (28) and by the "alloxan 305" method (29).

As noted in the first part of this study (15) the nitroprusside method is unsatisfactory as a measure of mercaptide formation. In experiments involving the meas- 
urement of thiols in the presence of PMB, the "alloxan 305 " method was used.

Techniques applicable to studies in rats. The experiments were made on large ( 400 to $500 \mathrm{~g}$ ) males from a Bartonella-free strain (Charles River C.D.) of SpragueDawley rat. Small volumes (5 to $10 \mathrm{ml}$ ) of rat blood in ACD were labeled with $\mathrm{Na}_{2} \mathrm{Cr}^{51} \mathrm{O}_{4}$ as described above. The labeled cells were incubated with the appropriate sulfhydryl inhibitor for 1 hour, washed, and injected by tail vein into each of several other recipient animals. The usual dose of injected cells was $1.0 \mathrm{ml}$ of a 25 per cent cell suspension containing 1 to $3 \mu \mathrm{c}$ of $\mathrm{Cr}^{51}$.

At various intervals after injection the animals were sacrificed; cardiac blood, spleen, liver, kidneys, lungs, and femurs were removed and counted as described previously (30). Intact red cells were obtained from the spleens of these animals by gentle homogenization of that organ in a loosely fitting Potter-Elvejhem homogenizer. This homogenate, containing released, radioactive, splenic red cells, was added to hypotonic salt solutions and the osmotic fragility of the labeled cells determined as described above.

Phagocytosis studies. The phagocytosis of sulfhydrylinhibited red cells was studied by means of the test-tube technique outlined by Packer and colleagues (31) and also by a modified Rebuck and Crowley window technique (32) as follows. Sulfhydryl-inhibited human red cells in fresh autologous serum were added to the forearm of the donor 3 hours after sterile inflammation had been produced by scarification. At various intervals thereafter the cover glasses were removed and examined for erythrophagocytosis. Studies of phagocytosis in rats were made by examining splenic imprints at various intervals after intravenous injection of sulfhydryl-inhibited cells.

\section{RESULTS}

Studies of NEM-treated cells in man. Autogenous, $\mathrm{Cr}^{51}$-labeled red cells that had been treated with small, nonhemolyzing doses of NEM were rapidly removed from the normal circulation, as

TABLE I

Effects of various doses of NEM on red cell GSH and red cell survival in man

\begin{tabular}{ccc}
\hline \hline NEM conc. & Red cell GSH & $\mathrm{Cr}^{51}$ \\
\hline$\mu$ moles $/$ ml $R B C$ & $\begin{array}{c}m g / 100 \mathrm{ml} \\
\text { red cells }\end{array}$ & $\mathrm{T}_{60}$ \\
0 & 60 & $*$ \\
1 & 24 & 22 days \\
2.3 & 7 & 26 days \\
5 & 0 & $3 \mathrm{hr}$ \\
20 & 0 & $22 \mathrm{~min}$ \\
80 & 0 & $8 \mathrm{~min}$
\end{tabular}

* Control observations on the half-survival of red cells incubated with saline alone were not made. The survival of cells treated with small amounts of NEM presented in the table is within the accepted normal range for the $\mathrm{Cr}^{51}$ technique (2). shown in the left portion of Figure 1. The dose portrayed (20 $\mu$ moles NEM per ml red cells) caused complete blockade of intracellular GSH, cessation of cellular glycolysis, a moderate leakage of $\mathrm{K}^{+}$, and a slight reduction in cell volume and osmotic fragility. The cells appeared normal microscopically. The injected red cells were cleared in an exponential fashion with a half-clearance time $\left(T_{50}\right)$ of 22 minutes. The osmotic fragility, and hence the spheroidicity, of the circulating labeled cells did not increase prior to sequestration, as measured by the $\mathrm{Cr}^{51}$ differential osmotic fragility technique. The lower left portion of Figure 1 demonstrates that the cells so treated were selectively trapped in the spleen. This sequestration was not followed by hemoglobinemia. However, plasma bilirubin levels rose from a baseline level of 0.4 to $1.4 \mathrm{mg}$ per $100 \mathrm{ml}$ at 2 hours, and $1.6 \mathrm{mg}$ per $100 \mathrm{ml}$ at 4 hours after injection of $200 \mathrm{ml}$ of a 50 per cent suspension of NEMtreated cells. There was no effect on either circulating white cell levels or body temperature of the injected subjects.

The special role of the spleen in trapping red cells so treated with NEM was further studied on two occasions in an otherwise normal individual who had been splenectomized several months earlier because of a traumatic splenic rupture. As shown in the right portion of Figure 1, NEMtreated cells survived over 30 times longer in the splenectomized patient $\left(T_{50}=11\right.$ hours $)$ than in normal individuals. During this slow clearance of treated cells no increase in their osmotic fragility was observed in vivo.

The effects of various doses of NEM on red cell GSH and on red cell survival are compared in Table I. Amounts of NEM sufficient to block as much as 90 per cent of cellular GSH had no effect on cell survival. At doses just sufficient to block all GSH, red cell survival was impaired, with a slow selective sequestration of labeled cells by the spleen (Figure 2, left portion). Cells so treated were of normal size, shape, and fragility. In contrast, much larger doses of NEM, in calculated excess of that necessary to block all the sulfhydryl groups of cellular hemoglobin as well as of GSH (15), caused some spherocytosis, increased osmotic fragility, and slight autohemolysis. Red cells treated with these large doses were rapidly removed from the circulation with seques- 


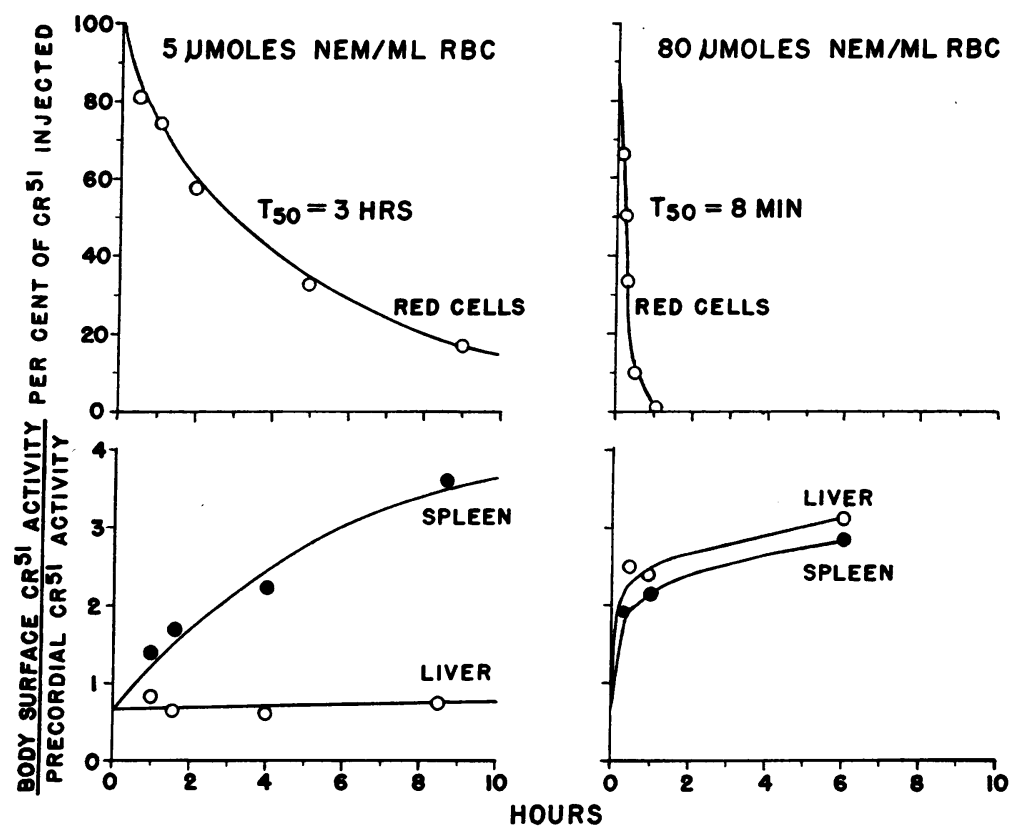

Fig. 2. EFFect of varying Doses of NEM ON RED CELl SEQUESTRATion. Red cells treated with low doses of NEM, just sufficient to inhibit red cell GSH, are removed slowly from the circulation specifically by the spleen (left). Cells treated with high doses of NEM, sufficient to cause spherocytosis and subsequently slight autohemolysis in vitro, disappear very rapidly, being trapped by the liver as well as by the spleen (right).

tration in the liver as well as in the spleen (Figure 2 , right portion). This rapid sequestration was also attended by hyperbilirubinemia, beginning 1 hour after injection, but not by hemoglobinemia.

These observations, summarized in Table I, and indicating that relative decreases in intracellular GSH levels were unimportant, per se, to cell survival as long as some measurable sulfhydryl activity remained, were further investigated. Labeled autologous red cells, treated with NEM so that 90 per cent of their original GSH had been inhibited, were administered to two patients on moderately high doses of the oxidant drug primaquine ${ }^{4}(60 \mathrm{mg}$ of the base per day). In both patients normal cell survival was observed, indicating that these cells responded normally to added oxidant-drug stress in contrast to congenitally GSH-deficient cells, whose lowered GSH levels are secondary to a deficiency of G6PD (9). It is possible that the normal survival of these NEM-treated red cells reflected a reversal of the

4 Primaquine diphosphate, generously supplied by Dr. George D. Wessinger, Sterling-Winthrop Institute, Division of Sterling Drug, Inc., Rensselaer, N. Y. inhibition of GSH or a restoration of GSH levels by new synthesis in vivo. On the other hand, the blockade of intracellular GSH by NEM was not reversible in vitro, even in cells with continuing glycolysis or in cells that were subsequently resuspended in either cysteine, which permeates the red cell, or GSH, which does not.

Studies of PMB-treated cells in man. Red cells incubated with small doses of the nonpermeable inhibitor, PMB ( 4 to $5 \mu$ moles per ml cells), were shown to contain normal amounts of intracellular $\mathrm{GSH}$, to consume glucose and produce lactate in normal fashion, and yet to leak $\mathrm{K}^{+}(15)$. These cells, although metabolically active, when reinjected were rapidly removed from the circulation, being trapped mainly in the spleen (Figure 3). The osmotic fragility of these labeled circulating cells remained normal during their brief period of survival in vivo. Sequestration was followed by a bilirubin peak in the plasma but not by hemoglobinemia. These cells, therefore, despite their normal glycolytic activity and normal GSH levels, behaved in a fashion analogous to that of red cells treated with sufficient NEM to block all GSH. 
As with NEM, doses of PMB great enough to cause uniform spherocytosis and slight autohemolysis caused more rapid cell disappearance accompanied by marked hepatic as well as splenic sequestration. Doses less than that cited in Figure 3 caused lesser rates of cell sequestration. There was no clear threshold dose as with NEM. Thus a dose of $1 \mu$ mole PMB per $\mathrm{ml}$ red cells caused the rapid destruction of a minor population of cells (about 30 to 40 per cent of those injected), while the remainder survived normally.

That the survival of $\mathrm{Cr}^{51}$ in sulfhydryl-inhibited red cells was not spuriously shortened in vivo as the result of a possible increased elution of the isotope is indicated by the following: 1) radioactivity accumulated in specific organs rather than appearing in the plasma, other circulating red cells, or urine, as would be the case with freed $\left.\mathrm{Cr}^{51}(24) ; 2\right)$ in the absence of the spleen the survival of $\mathrm{Cr}^{51}$ in inhibited red cells was markedly prolonged; 3 ) the disappearance of $\mathrm{Cr}^{51}$ labeled cells from the blood stream was followed by hyperbilirubinemia and, with the bigger doses of inhibitor, by hemoglobinemia; 4) in animals (see below) the injection of sulfhydryl-inhibited red cells was followed by splenic engorgement

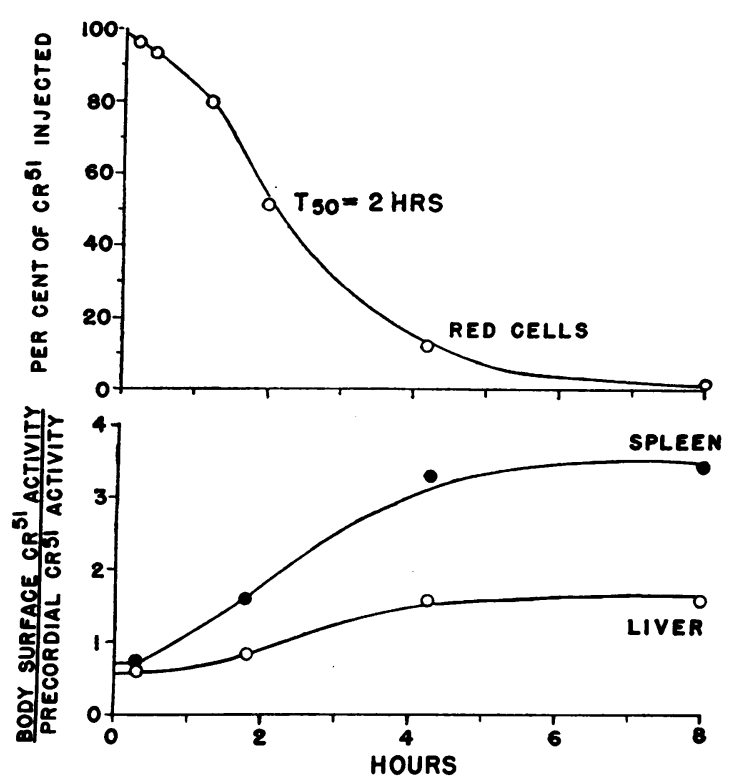

Fig. 3. Destruction of Red cells treated with PMB. Red cells treated with PMB, $5 \mu$ moles per ml red cells, have normal glycolytic capacity and normal GSH level, yet are removed rapidly, principally by the spleen.

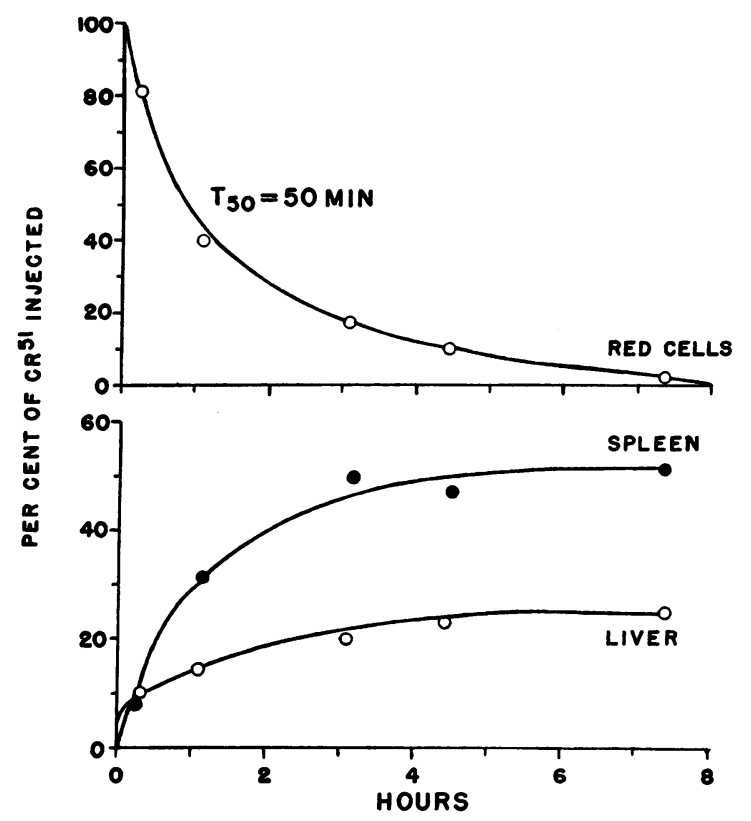

Fig. 4. DEstruction OF SULFHYDRYL-INHIBITED RED CELLS IN RATS. Rat red cells treated with NEM, 25 $\mu$ moles per $\mathrm{ml}$ red cells, disappeared rapidly from the circulation. Sequestration of these cells was predominantly in the spleen. Cells treated with PMB (not shown) behaved in a similar fashion.

with red cells and, after a delay, by evidence of erythrophagocytosis.

Studies of phagocytosis of sulfhydryl-inhibited red cells in man. Although autogenous A-positive red cells exposed for short periods in vitro to complement-fixing anti-A underwent erythrophagocytosis when placed subsequently in skin-window preparations, this phenomenon was not observed when sulfhydryl-inhibited red cells were employed. Similarly, phagocytosis of inhibited cells by autologous granulocytes in the presence of fresh serum was not demonstrable in the test tube, whereas in parallel preparations anti-A did induce erythrophagocytosis of A-positive red cells.

Studies of sulfhydryl-inhibited red cells in rats. The behavior of sulfhydryl-inhibited cells in the rat circulation was similar to that found in man. Both NEM-treated cells (Figure 4) and PMBtreated cells disappeared from the circulation within 4 to 6 hours after injection. With the doses employed, total spleen uptake was 2 to 5 times that of the liver and splenic uptake was 30 to 80 times that of the liver on a gram-for-gram basis. In addition. as in man, a marked prolonga- 
tion of survival of sulfhydryl-inhibited cells was found in splenectomized rats, despite enhanced hepatic uptake in these animals.

As in man, the trapping of sulfhydryl-inhibited rat red cells by splenic tissue was not necessarily preceded by their sphering, as measured by the osmotic fragility of these circulating, labeled cells. The gentle homogenization of rat spleens at varying intervals after cell injection caused the release of intact labeled cells from this organ and allowed their fragility to be measured at such times. Figure 5 illustrates the radioactive osmotic fragility curves so obtained. It is noted that the initial (16-minute) fragility of sequestered cells was nearly normal. After 1 hour, at a time when 45 per cent of injected cells had already been removed from the circulation, an osmotically fragile population appeared. Still greater increases in fragility were found in those few intact cells residing for more prolonged periods in the spleen (Figure 5).

Evidence that splenic trapping of these cells was not primarily a function of erythrophagocytosis was derived from direct microscopic examination of imprints of spleen removed at varying times after injection of the altered cells. Initially, no evidence of abnormal macrophage inclusions could be demonstrated. However, after 1 to 2 hours there was a marked and consistent increase in erythrophagocytosis, mainly evidenced by the appearance of large, colorless, cytoplasmic vacuoles in granulocytes and histiocytes.

\section{DISCUSSION}

These studies have shown that sulfhydryl-inhibited red cells are removed rapidly and completely from the human and rat circulations. Appropriately inhibited cells, although of normal size and shape, are trapped and destroyed almost entirely in the spleen by mechanisms unknown at present.

The spleen as a trap for sulfhydryl-inhibited red cells. The specificity with which the spleen traps sulfhydryl-deficient cells is striking and may even exceed that of red cells coated with incomplete

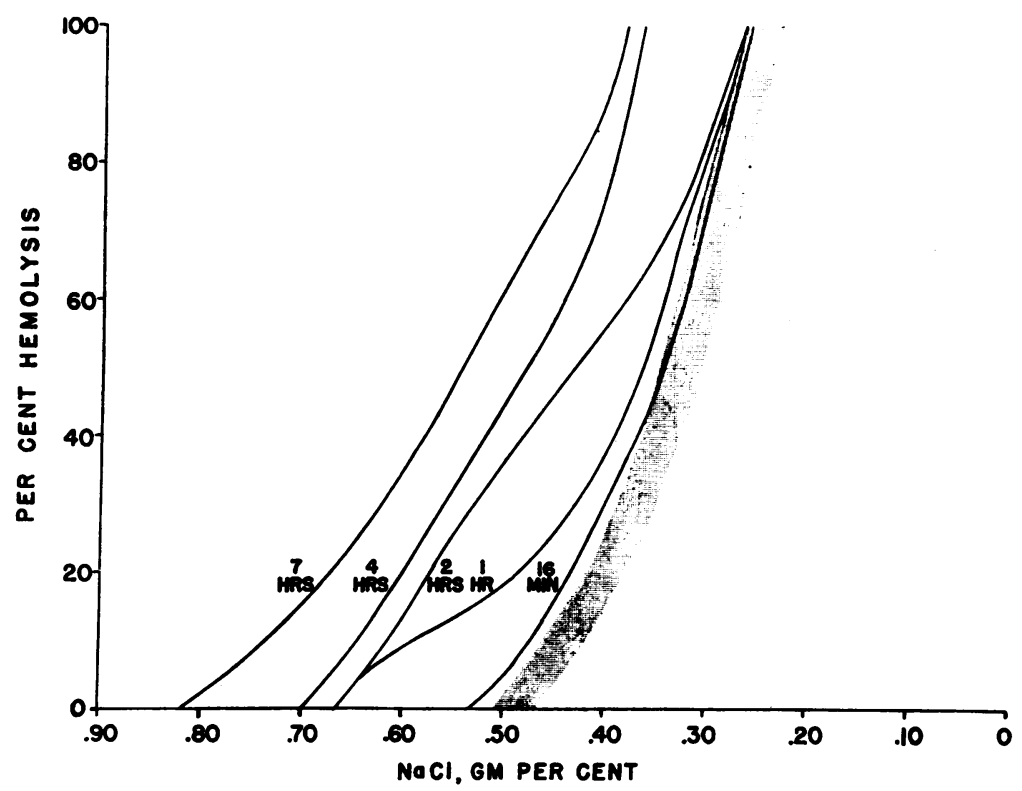

Fig. 5. Changes in OSMOtic FRAgility of NEM-treated Rat RED CELls DURING SEQUESTRATION IN THE SPLEEN. Labeled, NEM-treated red cells sequestered in the rat spleen show a progressive increase in osmotic fragility as compared with similarly treated red cells incubated in vitro (shaded area). Sixteen minutes after injection red cells trapped in the spleen are still of normal osmotic fragility (16-min curve). At 1 hour an increase in the fragility of part of the labeled cell population is apparent in the spleen (1-hr curve, lower portion) although labeled cells still in the circulation are of normal fragility at this time (not shown). Progressively greater increases in fragility are noted in the curves for 2,4 , and 7 hours, respectively. 
(e.g., anti-D) antibody. Antibody-coated cells (33) and sulfhydryl-inhibited cells are comparably half-cleared by the normal spleen at a rate of 3 to 4 per cent per minute, a rate that is presumably limited by the rate of splenic blood flow (34). In the absence of the spleen the rate of clearance of sulfhydryl-inhibited cells was reduced to $1 / 30$ of that found in the normal circulation, as compared with antibody-coated cells whose rate of removal in splenectomized subjects is about $1 / 10$ of normal (35). It should be noted that, with both sulfhydryl-inhibited and antibody-coated cells (36), the pattern of sequestration and thus the specificity of the spleen are influenced by quantitative factors.

The means by which the spleen so specifically recognizes altered cells remains enigmatic. The ability of the spleen to act as a "filter" for abnormally shaped cells has been well documented in conditions that occur naturally, such as hereditary spherocytosis (37) and, possibly, hereditary elliptocytosis (38). Similarly, experimentally produced spherocytes (39) have been effectively filtered from the circulation by the spleen. The cells in the present studies, however, appeared of normal shape and size upon microscopic inspection, and did not show increased osmotic fragility either prior to or during their circulation and sequestration. Indeed, it was found that sulfhydrylinhibited red cells trapped in rat spleens were of nearly normal osmotic fragility for at least 16 minutes after trapping. Only after more prolonged sequestration was there an increase in osmotic fragility of spleen-sequestered red cells, whereas no such change occurred during incubation of these cells for the same time in plasma at $37^{\circ} \mathrm{C}$ in vitro. Thus, we found that spheroidicity was imparted by exposure of these cells to the spleen. With sulfhydryl-inhibited red cells, as is probably the case with antibody-coated cells $(40-42)$, sequestration is not preceded by a spheroidal change in the cells but, rather, induces it.

It has been proposed that the spleen recognizes globulin-coated cells by a change in their surface characteristics, for instance, by their propensity to agglutinate in rouleaux-forming media (43). In a similar fashion, the trapping of sulfhydrylinhibited cells may be secondary to physicochemical alteration of the cell membrane itself. In support of this contention is the finding that, at the low doses used in these experiments, $\mathrm{PMB}$ does not penetrate the intact red cell membrane (15); presumably, therefore, it induces rapid splenic sequestration by direct injury to this membrane only. NEM, on the other hand, was shown to enter the red cell freely, thereby inhibiting glycolysis and binding intracellular GSH. However, evidence that this sulfhydryl inhibitor also owed its in vitro hemolytic activity to direct membrane injury was presented (15).

In order to assess the possible part, if any, that the inhibition of glycolysis, per se, might play in the destruction of NEM-treated cells in vivo, the behavior of fluoride- and arsenate-treated red cells was studied in man. It was found that cells treated with arsenate disappeared slowly from the human circulation over 24 hours, and were trapped primarily in the liver, results confirming the data of Harris, McAlister and Prankerd (39). Cells treated with fluoride for 6 hours in vitro, under conditions shown to reduce cellular ATP to 30 per cent of original levels (44), disappeared as two separate populations. Approximately half the treated cells were removed from the human circulation with a half-clearance of 24 hours, sequestration being equal in liver and spleen, while the remainder survived normally. The cells of this latter population presumably were able to expel fluoride ion in exchange for chloride prior to the onset of irreversible cellular damage. Despite such prolonged metabolic inhibition in both the arsenate- and fluoride-treated cells, little tendency for these cells to accumulate in the spleen was noted, in contrast to observations with NEMtreated cells. Thus it is clear that cessation of glycolysis per se leads to a delayed injury to the cell in which several hours are required for minimal impairment of viability, in contrast to sulfhydryl-inhibited cells, in which irreversible injury occurs within a few minutes. These observations in vivo support the earlier conclusion (15) that NEM and PMB do not act merely to block regeneration of high-energy phosphate compounds such as ATP. The delayed and relatively mild effects of fluoride and arsenate upon red cell survival also emphasize the specificity of sulfhydryl inhibition in the mechanism of splenic sequestration.

Unlike antibody-coated cells, sulfhydryl-deficient red cells do not agglutinate in Coombs sera 
or in polyvinylpyrrolidone. Furthermore, sulfhydryl-inhibited cells are not abnormally prone to form rouleaux as measured microscopically or by sedimentation rates. However, a change in electrostatic potential of the sulfhydryl-deficient red cell membrane might underlie its propensity to be trapped by the spleen. In this regard, it was suggested by the early studies of Robinson (45) that differences in the affinity of the spleen for colloidal particles might relate to their electrical properties. Such a hypothesis remains for study. In addition, a possible relation of membrane sulfhydryl activity to cell "stickiness" was shown in the studies of Philipson and Choppin, who blocked with sulfhydryl inhibitors the attachment of viruses to red cells (46) and to tissue culture cells (47). In addition, it has been shown that modification of leukocytes by PMB inhibits their "adhesiveness" to siliconized glass beads (48). However, the relevance of these in vitro alterations of cellular adhesiveness to the mechanism of red cell trapping by the spleen in the present studies remains conjectural.

Enhanced phagocytosis of sulfhydryl-inhibited cells could not be demonstrated in the test tube, in skin-window preparations, or by early examination of rat splenic imprints after intravenous injection of these cells. It seems unlikely that phagocytosis alone, unaccompanied by other trapping devices, was responsible for cell removal; one would have to postulate that splenic macrophages were 180 to 240 times as plentiful or as avid for red cells as were hepatic macrophages, since hepatic clearance was only $1 / 30$ that of the spleen while its blood flow is probably 6 to 8 times as great.

Relation of biochemical alterations in vitro to behavior in vivo of sulfhydryl-inhibited red cells. With both NEM and PMB the minimal dose that affected cell survival in vivo was the same as the minimal dose that caused $\mathrm{K}^{+}$leakage in vitro. In addition, with NEM-treated cells there was also a correspondence of diminished cell survival in vivo to impaired glycolysis and to complete inhibition of GSH. No such association existed with PMB-treated cells, whose survival was diminished despite unaltered cellular glycolytic capacity and GSH concentration. The possibility that $\mathrm{K}^{+}$loss was primarily involved in this loss of viability was discounted by the fluoride experi- ments in which red cell survival was relatively little impaired despite marked loss of cellular $\mathrm{K}^{+}$. A second association was that the propensity of altered red cells to be sequestered in the liver, and to undergo autohemolysis upon prolonged incubation, was coincident with the tendency of these cells to take up $\mathrm{Na}^{+}$and to manifest spherocytosis and an increase in osmotic fragility. Again, it is probable that the cation changes were correlative rather than causative. Finally, the close association of membrane sulfhydryl inhibition and disturbed cation control with diminished cell viability should be emphasized, as should the lack of association of intracellular sulfhydryl activity and glycolysis with in vivo survival.

The present studies, in conjunction with the earlier findings of Beutler and colleagues $(12,28)$, suggest that, in the course of poisoning by oxidant drugs such as phenylhydrazine and the antimalarials, the eventual product of the intracellular oxidation that critically affects red cell survival is the destruction of membrane sulfhydryl groups. Other hemolytic agents, such as mercury and possibly fava beans, as well as certain antibodies, may act by directly affecting these groups. When injury is relatively mild, splenic sequestration would predominate. When injury is relatively severe, hepatic sequestration and intravascular hemolysis would ensue.

The relevance of these studies to normal red cell senescence is more difficult to evaluate. Although definitive studies of sulfhydryl activity of senescent red cells have not been reported, the expectation that such activity would be diminished, equally with the decreased concentration of numerous enzymes and glycolytic intermediates in aged cells, seems reasonable. The decreased activity of GSH in adult red cells when compared with reticulocytes (49) fits this conjecture. It is suggested that diminished sulfhydryl activity in senescent red cell membranes might lead to the sequestration and destruction of these cells. The finding that reduced GSH also protects hemoglobin in vitro from auto-oxidative breakdown $(50,51)$ leads one to speculate as follows: 1) a failure of glycolytic activity in senescent cells leads to diminished intracellular sulfhydryl levels and an increase in hemoglobin oxidized; 2) this leads to diminished membrane sulfhydryl activity and thus to cell sequestration and destruction. The circu- 
lation is thereby freed of cells containing inefficient heme protein through the common intermediate of diminished cellular sulfhydryl concentrations.

\section{SUMMARY}

Red cells of human or rat exposed in vitro to sublytic amounts of the sulfhydryl inhibitors Nethylmaleimide (NEM) and $p$-mercuribenzoate (PMB) are nonviable in vivo. Loss of viability is related to the inhibition of membrane sulfhydryl groups but is unrelated per se to intracellular sulfhydryl levels or to the over-all rate of cellular glycolysis. An association, however, does exist between the ability of these cells to maintain cation gradients in vitro and their ability to survive in vivo.

Red cells treated with small doses of sulfhydryl inhibitor were of normal appearance and fragility and slowly lost $\mathrm{K}^{+}$; such cells on reinjection were trapped by the spleen with remarkable selectivity. Sequestration does not appear to depend upon changes in red cell shape, increased agglutinability, or erythrophagocytosis. After their sequestration in the spleen these red cells showed a progressive increase in osmotic fragility. Larger doses of inhibitor caused $\mathrm{Na}^{+}$and water ingress, spherocytosis, and a more rapid hepatic, as well as splenic, sequestration.

Since inhibition of high-energy phosphate metabolism in red cells by arsenate caused a delayed, slow destruction of red cells in vivo, and since cessation of anaerobic glycolysis and $\mathrm{K}^{+}$depletion in red cells by exposure for several hours to fluoride had comparatively little effect upon their subsequent survival, it is concluded that membrane sulfhydryl groups are uniquely important to cell viability.

It is suggested that a loss of membrane sulfhydryl activity may be the decisive hemolytic event common to a number of processes, including the Heinz body anemias and normal cellular aging.

\section{REFERENCES}

1. London, I. M. Metabolism of the mammalian erythrocyte. Bull. N. Y. Acad. Med. 1960, 36, 79.

2. Prankerd, T. A. J. The Red Cell; An Account of Its Chemical Physiology and Pathology. Springfield, Ill., Thomas, 1961.

3. Allison, A. C., and Burn, G. P. Enzyme activity as a function of age in the human erythrocyte. Brit. J. Haemat. 1955, 1, 291.

4. Marks, P. A., Johnson, A. B., Hirschberg, E., and Banks, J. Studies on the mechanism of aging of human red blood cells. Ann. N. Y. Acad. Sci. 1958, 75, 95.

5. Löhr, G. W., Waller, H. D., Karges, O., Schlegel, B., and Müller, A. A. Zur Biochemie der Alterung menschlicher Erythrocyten. Klin. Wschr. 1958, 36, 1008.

6. Alving, A. S., Tarlov, A. R., Brewer, G., Carson, P. E., Kellermeyer, R. W., and Long, W. K. Glucose6-phosphate dehydrogenase deficiency: Some biological implications. Trans. Ass. Amer. Phycns. 1960, 73, 80.

7. Brewer, G. J., Tarlov, A. R., and Kellermeyer, R. W. The hemolytic effect of primaquine. XII. Shortened erythrocyte life span in primaquine-sensitive male Negroes in the absence of drug administration. J. Lab. clin. Med. 1961, 58, 217.

8. Valentine, W. N., Tanaka, K. R., and Miwa, S. A specific erythrocyte glycolytic enzyme defect (pyruvic kinase) in three subjects with congenital nonspherocytic hemolytic anemia. Trans. Ass. Amer. Phycns. 1961, 74, 100.

9. Beutler, E. The hemolytic effect of primaquine and related compounds: A review. Blood 1959, 14, 103.

10. Jandl, J. H., Engle, L. K., and Allen, D. W. Oxidative hemolysis and precipitation of hemoglobin. I. Heinz body anemias as an acceleration of red cell aging. J. clin. Invest. 1960, 39, 1818.

11. Benesch, R. E., and Benesch, R. Relation between erythrocyte integrity and sulfhydryl groups. Arch. Biochem. 1954, 48, 38.

12. Beutler, E., Dern, R. J., Flanagan, C. L., and Alving, A. S. The hemolytic effect of primaquine. VII. Biochemical studies of drug-sensitive erythrocytes. J. Lab. clin. Med. 1955, 45, 286.

13. Sansone, G., and Segni, G. L'instabilità del glutatione ematico (GSH) nel utilizzazione di un test selettivo, introduzione al problema genetico, favismo; Boll. Soc. ital. Biol. sper. 1957, 33, 1057.

14. Newton, W. A., Jr., and Bass, J. C. Glutathionesensitive chronic nonspherocytic hemolytic anemia (abstract). J. Dis. Child. 1958, 96, 501.

15. Jacob, H. S., and Jandl, J. H. Effects of sulfhydryl inhibition on red blood cells. I. Mechanism of hemolysis. J. clin. Invest. 1962, 41, 779.

16. Jacob, H. S., and Jandl, J. H. Effect of membrane sulfhydryl deficiency on the shape and survival of red cells. Clin. Res. 1961, 9, 162.

17. Tsen, C. C., and Collier, H. B. The relationship between the glutathione content of rat erythrocytes and their hemolysis by various agents in vitro. Canad. J. Biochem. 1960, 38, 981.

18. Morell, S. A., Ayers, V. E., and Greenwalt, T. J. Reaction of N-ethyl-maleimide (NEM) with intact erythrocytes. Fed. Proc. 1959, 18, 290.

19. Malloy, H. T., and Evelyn, K. A. The determination of bilirubin with the photoelectric colorimeter. J. biol. Chem. 1937, 119, 481.

20. Zieve, L., Hill, E., Hanson, M., Falcone, A. B., and Watson, C. J. Normal and abnormal variations 
and clinical significance of the one-minute and total serum bilirubin determinations. J. Lab. clin. Med. 1951, 38, 446.

21. Ham, T. H. A Syllabus of Laboratory Examinations in Clinical Diagnosis. Critical Evaluation of Laboratory Procedures in the Study of the Patient, Rev. ed., L. B. Page and P. J. Culver, Eds. Cambridge, Harvard Univ. Press, 1960.

22. Jandl, J. H. Modern views of immunohematology in Proc. VIIth Int. Congr. of the Int. Society of Hematology. New York, Grune \& Stratton, 1960, vol. 1, Reports, p. 45.

23. Griggs, R. C., Weisman, R., Jr., and Harris, J. W. Alterations in osmotic and mechanical fragility related to in vivo erythrocyte aging and splenic sequestration in hereditary spherocytosis. J. clin. Invest. 1960, 39, 89.

24. Jandl, J. H., Greenberg, M. S., Yonemoto, R. H., and Castle, W. B. Clinical determination of the sites of red cell sequestration in hemolytic anemias. J. clin. Invest. 1956, 35, 842.

25. Nelson, N. A photometric adaptation of the Somogyi method for the determination of glucose. J. biol. Chem. 1944, 153, 375.

26. Barker, S. B., and Summerson, W. H. The colorimetric determination of lactic acid in biological material. J. biol. Chem. 1941, 138, 535.

27. Grunert, R. R., and Phillips, P. H. A modification of the nitroprusside method of analysis for glutathione. Arch. Biochem. 1951, 30, 217.

28. Beutler, E. The glutathione instability of drugsensitive red cells. A new method for the in vitro detection of drug sensitivity. J. Lab. clin. Med. 1957, 49, 84.

29. Patterson, J. W., and Lazarow, A. Determination of glutathione in Methods of Biochemical Analysis, D. Glick, Ed. New York, Interscience, 1955, vol. 2, p. 259.

30. Jandl, J. H. The agglutination and sequestration of immature red cells. J. Lab. clin. Med. 1960, 55, 663.

31. Packer, J. T., Greendyke, R. M., and Swisher, S. N. The inhibition of erythrophagocytosis in vitro by corticosteroids. Trans. Ass. Amer. Phycns. 1960, 73, 93.

32. Rebuck, J. W., and Crowley, J. H. A method of studying leukocytic functions in vivo. Ann. N. Y. Acad. Sci. 1955, 59, 757.

33. Jandl, J. H. Sequestration by the spleen of red cells sensitized with incomplete antibody and with metallo-protein complexes (abstract). J. clin. Invest. 1955, 34, 912.

34. Veall, N., as quoted in Mollison, P. L., and Cutbush, M. Use of isotope-labelled red cells to demonstrate incompatibility in vivo. Lancet 1955, 1, 1290.

35. Jandl, J. H., Jones, A. R., and Castle, W. B. The destruction of red cells by antibodies in man. I. Observations on the sequestration and lysis of red cells altered by immune mechanisms. J. clin. Invest. 1957, 36, 1428.
36. Jandl, J. H., and Kaplan, M. E. The destruction of red cells by antibodies in man. III. Quantitative factors influencing the patterns of hemolysis in vivo. J. clin. Invest. 1960, 39, 1145.

37. Emerson, C. P., Jr., Shen, S. C., Ham, T. H., Fleming, E. M., and Castle, W. B. Studies on the destruction of red blood cells. IX. Quantitative methods for determining the osmotic and mechanical fragility of red cells in the peripheral blood and splenic pulp; the mechanism of increased hemolysis in hereditary spherocytosis (congenital hemolytic jaundice) as related to the functions of the spleen. Arch. intern. Med. 1956, 97, 1.

38. Dacie, J. V. The Haemolytic Anaemias, 2nd ed. Part I. The Congenital Anaemias. New York, Grune \& Stratton, 1960, p. 164.

39. Harris, I. M., McAlister, J. M., and Prankerd, T. A. J. The relationship of abnormal red cells to the normal spleen. Clin. Sci. 1957, 16, 223.

40. Muir, R., and M'Nee, J. W. The anaemia produced by a haemolytic serum. J. Path. Bact. 1911-1912, 16,410 .

41. Banti, G. Splénomégalie hémolytique anhémopoiétique; le rôle de la rate dans l'hémolyse. Sem. méd. (Paris) 1913, 33, 313.

42. Castle, W. B., Ham, T. H., and Shen, S. C. Observations on the mechanism of hemolytic transfusion reactions occurring without demonstrable hemolysin. Trans. Ass. Amer. Phycns. 1950, 63, 161.

43. Jandl, J. H., and Castle, W. B. Agglutination of sensitized red cells by large anisometric molecules. J. Lab. clin. Med. 1956, 47, 669.

44. Nakao, M., Nakao, T., and Yamazoe, S. Adenosine triphosphate and maintenance of shape of the human red cells. Nature (Lond.) 1960, 187, 945.

45. Robinson, W. L. Some points on the mechanism of filtration by the spleen. Amer. J. Path. 1928, 4, 309.

46. Philipson, L., and Choppin, P. W. On the role of virus sulfhydryl groups in the attachment of enteroviruses to erythrocytes. J. exp. Med. 1960, 112, 455.

47. Choppin, P. W., and Philipson, L. The inactivation of enterovirus infectivity by the sulfhydryl reagent p-chloromercuribenzoate. J. exp. Med. 1961, 113, 713.

48. Garvin, J. E. Factors affecting the adhesiveness of human leucocytes and platelets in vitro. J. exp. Med. 1961, 114, 51.

49. Scheuch, D., and Rapoport, S. M. Glutathion und Triosephosphatdehydrogenase-Aktivität in roten Blutzellen von Kaninchen. Klin. Wschr. 1960, 38, 757.

50. Allen, D. W., and Jandl, J. H. Oxidative hemolysis and precipitation of hemoglobin. II. Role of thiols in oxidant drug action. J. clin. Invest. 1961, 40, 454.

51. Harley, J. D., and Mauer, A. M. Studies on the formation of Heinz bodies. II. The nature and significance of Heinz bodies. Blood 1961, 17, 418. 